\title{
Sea Surface Temperature and Find Later Jet Variations over Arabian Sea During Summer Monsoon
}

\author{
B.Pushpanjali ${ }^{2}$, M. V. Subrahmanyam ${ }^{1^{*}}$ and K.P.R. Vittal Murty ${ }^{2}$ \\ ${ }^{1}$ Marine Science Department, Zhejiang Ocean University, Zhoushan, Zhejiang, China \\ ${ }^{2}$ Department of Environmental Sciences, Acharya Nagarjuna University, Guntur, AP, India
}

*Corresponding author: Subrahmanyam MV, Marine Science Department, Zhejiang Ocean University, Zhoushan, Zhejiang, China, Tel: +86-18368086386; E-mail: mvsm.au@gmail.com

Rec date: Feb 25, 2014; Acc date: Jun 10, 2014; Pub date: Jun 17, 2014

Copyright: @ 2014 Subrahmanyam MV et al. This is an open-access article distributed under the terms of the Creative Commons Attribution License, which permits unrestricted use, distribution, and reproduction in any medium, provided the original author and source are credited.

\begin{abstract}
Indian summer monsoon is important to study in relation with the air-sea interaction processes. Find later jet (FLJ) is a Low Level Jet observed at $850 \mathrm{mb}$ by which the moisture is transported to the Indian sub-continent from the Indian Ocean. In this connection it is important to observe FLJ intensity variations over Arabian Sea. In this article authors attempted to examine the Intraseasonal variability of FLJ intensities for the period 1980-2012 in relation to Sea Surface Temperature anomalies (SSTA) over Arabian Sea during summer monsoon season. As EI Nino and La Nina are affecting the summer monsoon rainfall, authors studied the variations in FLJ and SSTA and also evaluated the correlation between FLJ and SSTA during the above mentioned period. An apparent relationship is found between the intensity of FLJ and SSTA over Arabian Sea region. FLJ is increasing in July during an El Nino event and SSTA is higher positive anomalies.
\end{abstract}

Keywords: SSTA; Find later jet; El Nino; Summer monsoon

\section{Introduction}

Monsoon, generally defines as a system of winds characterized by a seasonal reversal of its direction. Indian Meteorological Department (IMD) defines it as the seasonal reversal of the wind direction along the shores of the Indian Ocean, especially in the Arabian Sea. The cross equatorial flow intensifies and as a jet blowing towards Indian subcontinent with higher intensity at $850 \mathrm{mb}$ level identified by Find later Findlater [1], and named as Find later jet. The winds coming from the southern Indian Ocean brings the moisture to Indian subcontinent. Pushpanjali [2,3] studied the climatology and variations of FLJ intensities in relation to summer monsoon and explained the influence of FLJ on monsoon circulation and having positive correlations with rainfall over Indian subcontinent.

Indian Ocean SST variability is most important to understand and assess the impacts of air sea interactions on the evolution and the potential predictability of climate and monsoon in the adjacent region. Earlier studies identified that the SST over the Arabian Sea may have important influences on the monsoon flow and associated rainfall. Saha [4-6] have postulated the possible effects of the SSTA and can be qualitatively described as warmer SSTAs (Sea surface temperature anomalies) and stronger winds may cause higher evaporation and the monsoon current may be more moist and unstable. Colder SSTAs may cause higher surface pressures and less evaporation over the Arabian Sea and this may reduce the cross-equatorial moisture flux and thus reduce the rainfall over India. Gradients of SST within the oceans are important in determining the location of precipitation over the tropics, including the monsoon regions [7]. A cool Arabian Sea SST leads to reduced Indian rainfall and vice versa [8-10]. Earlier studies $[8,11]$ have suggested that the Arabian Sea SST is important because of its possible role on the interannual variability of summer monsoon. The annual cycle of SST in the Indian Ocean is crucially important in establishing the monsoon circulation and rainfall [12]. Recent studies have identified that Indian Ocean SST has a strong seasonal variability and its variability is related to the ENSO variability [13-15]. The interannual SST variability in the Indian Ocean has to be mostly the result of external atmospheric forcing and internal oceanic variability. Shukla, Weare, Rao and Goswami $[8,11,16,17]$ have shown the possible relationship between SST variations over different parts of the Indian Ocean and monsoon activity over the Indian subcontinent. However, the wind, cloud and humidity, which determine the transfer of heat and moisture fluxes from ocean to the atmosphere, show significant variability in large excess and deficit monsoon rainfall years. It is well known that SST over Arabian Sea is influencing the summer monsoon over Indian sub-continent. The moisture which is transported from southern Indian Ocean to Indian subcontinent through Arabian Sea by FLJ is also another important parameter to study. SSTAs are believed to be important in affecting the atmospheric circulations. So, in this article we studied the relation between FLJ and sea surface temperature over Arabian Sea during the summer monsoon.

\section{Data and Methodology}

In this article, we studied the variation of wind and computed FLJ intensities over the core are of jet and SSTA during 1980-2012 to understand how the FLJ intensities and SSTA are related during summer monsoon months (JJAS). SSTA data is taken from National Oceanic and Atmospheric Administration (NOAA). NOAA optimum interpolation 0.25 degree SST blended with Advanced Very High Resolution Radiometer (AVHRR) data version 2 has been used to study. Two new high resolution analysis products have been developed using optimum interpolation (OI). The analyses have a spatial grid resolution of $0.25 \mathrm{deg}$. and temporal resolution of 1 day. A description of the OI analysis can be found in Reynolds [18]. For FLJ, need to study the wind pattern over the Arabian Sea before onset of summer 
monsoon through end of September. So for this work June through September data has been used. Since maximum intensities are observed at $850 \mathrm{mb}$ pressure level and confined to the area $\left(5^{\circ} \mathrm{N}-20^{\circ} \mathrm{N}\right.$ and $50^{\circ} \mathrm{E}-75^{\circ} \mathrm{E}$ ) which has been treated as core area for this study. We used the $850 \mathrm{mb}$ level winds obtained from National Centers for Environmental Prediction (NCEP) data [19] for computing the FLJ intensities and observed the variations. Both FLJ intensities and SSTA are taken between over the core area for analysis. In this study, FLJ intensities are computed daily and averaged for monthly and presented and discussed in this article.

\section{Results and Discussion}

Large internal SST variability projects directly onto the zonal SST gradient and can change its seasonal cycle. It can also affect the amount of moisture that is picked up by the FLJ and delivered to the Indian subcontinent during the SWM.

\section{Variation of SSTA and FLJ intensities Over Arabian Sea}

The SST is influenced by the moisture flux and the cloud cover over the Arabian Sea. So, naturally the SSTs (Sea surface temperatures) are less under active monsoon with large cloud clusters. Variation of composites of SSTA and FLJ intensities for the months June through September are shown in Figure 1 for the period of 1980 to 2012. Figure 1 illustrates the composite variations of SSTA (contours) with FLJ intensities (vectors) for the months of June through September (monsoon months). Higher SSTA can be observed at south west of Arabian Sea $\left(72^{\circ} \mathrm{E}\right.$ to $80^{\circ} \mathrm{E}$ and $10^{\circ} \mathrm{S}$ to $\left.2^{\circ} \mathrm{S}\right)$ and over northern Arabian Sea in June month. However over Somali coast SSTA is normal and there is a gradient of increasing SSTA towards central Arabian Sea. The intensity of wind increased and there is strong jet can be observed. However, lower SSTA can be seen over Somali coast.

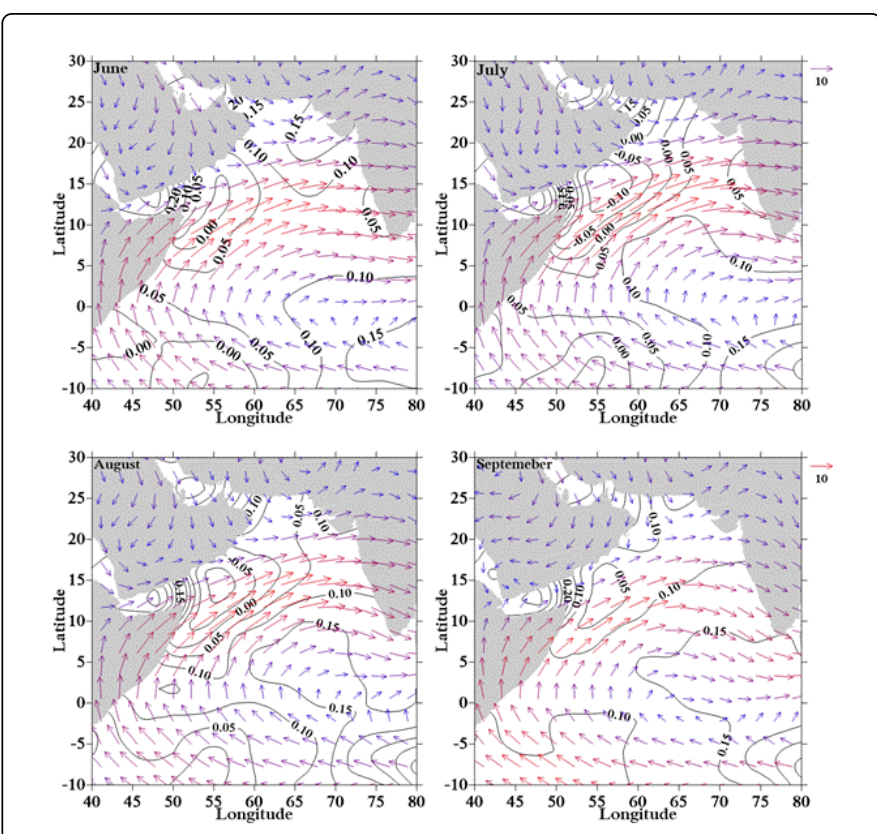

Figure 1: Variation of composites of Sea Surface Temperature (contours) and wind (vectors) during the period of 1980-2008
In July intensities of wind increased and there is a strong jet (Find later Jet) can be observed. The jet is blowing from west to east of Arabian Sea. However the SSTA showing negative anomalies over Somali coast, indicating there is an upwelling. Higher SSTA can be observed from the central to southeast of Arabian Sea. We can clearly observe the gradient of SSTAs from west to east of Arabian Sea. In August, the wind intensities are lower than July and the SSTAs are confined to north of Somali coast. Higher SSTA can be observed over central Arabian Sea. The areal extent of higher SSTA increased when compared with July. SSTA further increased during September month and the intensities of wind decreased. It reveals that wind intensities are increasing from June to July then decrease by September.

Over all composite analysis reveals that, the SSTAs are lower during June and July months over Somali coast, there is upwelling process happening when strong wind speed prevails. The FLJ facilitates Ekman pumping in the northern Arabian Sea, and equator ward-directed alongshore wind stress induces upwelling which lowers SST [20]. During August, the SSTAs are increasing and upwelling decline. However in the month of September we can find positive SSTAs over Somali coast, indicating that further upwelling process is absent due to further decrease in wind intensities. Over southeast Arabian Sea higher SSTAs can be observed during June and the areal extent is increasing through September. Further intrusion of higher SSTA can be observed up to central Arabian Sea during June through September. During the monsoon months we can observe the wind intensities are strong and bringing the moisture from southern Indian Ocean and Indian sub-continent acquire rain. Due to FLJ, which bringing the moisture, Indian sub-continent is experiencing rainfall during the monsoon months. The variations in FLJ diverge the moisture transport to Indian sub-continent leads to variations in rainfall. So it is important to study the FLJ over Arabian Sea during the monsoon months, mainly during June and July owing to Indian sub-continent experience the higher rainfall.

\section{SSTA and FLJ variations in the Core region over Arabian Sea}

The core region for the FLJ identified from the composite wind variations over Arabian Sea is between $5^{\circ} \mathrm{N}-20^{\circ} \mathrm{N}$ and $50^{\circ} \mathrm{E}-75^{\circ} \mathrm{E}$. To identify the variations of the core region of Find later jet, we used daily SSTA and wind intensities during the individual months and seasonal variations of entire period of study (1980-2012) and are given in figure 2. The variations during monsoon months (JJAS) and entire monsoon season for better understanding the dependence of FLJ and SSTA on monsoon circulation. During June, FLJ varied between $9 \mathrm{~m} / \mathrm{s}$ to $15 \mathrm{~m} / \mathrm{s}$ with positive and negative anomalies of SSTA. During 2003 we can find higher positive anomaly. During the month of July FLJ intensities are higher than June. We can observe lower FLJ during 1987, however SSTA are higher. During 2003 FLJ having higher intensities and SSTA are showing higher positive anomaly. During August FLJ intensities are lower than June. When FLJ intensities are high, lower SSTAs can be observed and vice versa. However, during 1997 higher FLJ intensities and higher SSTA can be found. In September FLJ intensities further decreased and when compared with other month's intensities. The highest FLJ intensity found is $11 \mathrm{~m} / \mathrm{s}$, however other months are having $15 \mathrm{~m} / \mathrm{s}$. In 1999 SSTAs are showing positive but FLJ intensities are varying between $7 \mathrm{~m} / \mathrm{s}$ and $11 \mathrm{~m} / \mathrm{s}$. The seasonal picture shows FLJ intensities are varying between $9 \mathrm{~m} / \mathrm{s}$ and $13 \mathrm{~m} / \mathrm{s}$ and SSTA are varying in -0.5 to 0.5 , however SSTA are showing positive anomalies from 2002. Year 2003 is associated with higher SSTA with FLJ intensity of $12 \mathrm{~m} / \mathrm{s}$. 


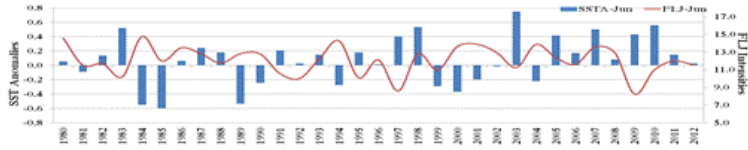

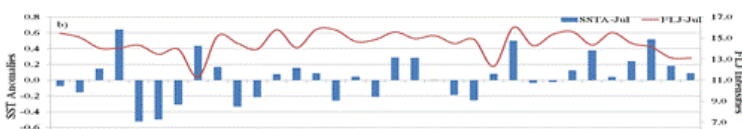

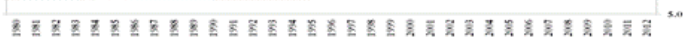

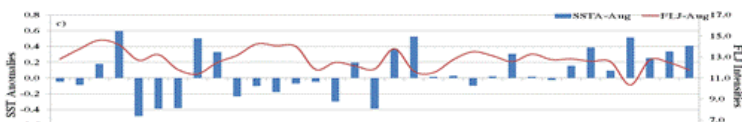

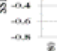

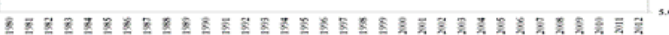

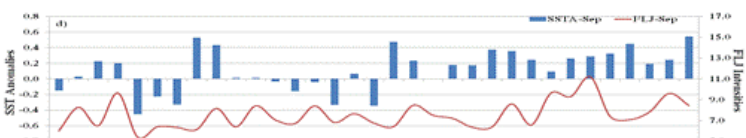

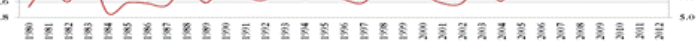

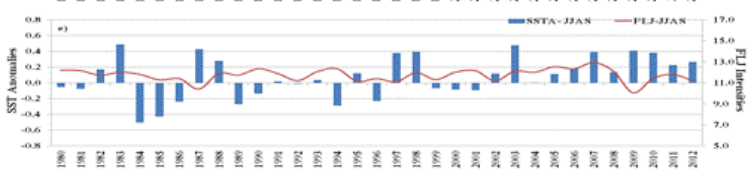

Figure 2: Variations of composites of SSTA and FLJ intensities over core area during (a) June (b) July (c) August (d) September and (e) seasonal (JJAS)

\section{Variations of SSTA and FLJ intensities during El Nino and La Nina years}

Figure 3 indicates the variation of composites of FLJ and SSTA during El Nino years over Arabian Sea. The intensities of FLJ during El Nino are lower than climatological intensities during June. SSTA demonstrate the increase in SSTA from west to east side of southern hemisphere over equator to $-10^{\circ} \mathrm{S}$, however higher SSTA can be observed in the northern Arabian Sea. The FLJ intensities increased during July; however the intensities are lower than composite intensity during study period. Same feature observed in June is revealed in July also with SSTA over southern Arabian Sea and the anomalies are increased. However over northern Arabian Sea SSTA decreased when compared with June month and over central Arabian Sea the SSTA increased. The upwelling feature observed over Somali coast is absent during June and July months. It indicates that the intensity of FLJ is lower, so which is not able to generate upwelling process, so there is warming of surface temperature, which can be revealed by SSTA. During August the intensities of FLJ decreased further with warming of SST. Over the west coast of India SSTA gradient can be observed from northern to southern. In the southern Arabian Sea SSTA increased further when compared with July and June. In September the FLJ decreased further and we can find there is no jet present especially in El Nino. SSTA are increased further when compared with other months and a positive gradient can be observed from northern to southern Arabian Sea. Over Somali coast we can find higher positive anomalies. If we compare the core intensities during El Nino events from the figure 2 , in the month of June, higher intensity can be found during 2004 and lower can be found in 2009. During 2002 June, the FLJ is $13 \mathrm{~m} / \mathrm{s}$ with almost normal SSTA. However in 1997, SSTA is positive with FLJ intensity of $9 \mathrm{~m} / \mathrm{s}$. In July month, FLJ intensities increased than June month. The highest FLJ intensity of $16 \mathrm{~m} / \mathrm{s}$ can be observed during 1991 and 1997 with SSTA 0.05 and 0.3 respectively. Higher SSTA of 0.5 can be found during 2002 with FLJ intensity of 12 $\mathrm{m} / \mathrm{s}$. In the August month of 1981 and 1991 experienced FLJ intensity of $14 \mathrm{~m} / \mathrm{s}$ with 0.2 and -0.2 SSTA. However lowest FLJ intensity of 10 $\mathrm{m} / \mathrm{s}$ can be found during 2009 with higher SSTA of 0.5. In September core intensity of FLJ is found to be $6 \mathrm{~m} / \mathrm{s}$ with variations in SSTA between -0.05 and 0.5. In the Seasonal, FLJ varied between $10 \mathrm{~m} / \mathrm{s}$ and $12 \mathrm{~m} / \mathrm{s}$ with SSTA varied between 0 and 0.4 . From the above given variations we can conclude that, during El Nino years, the FLJ intensities are lower than composite FLJ intensities with positive SSTA. However the rainfall over the Indian subcontinent experienced lower rainfall. This may be due to the effect of IOD over Indian Ocean. As a result of which the rainfall is lower than normal if negative IOD and normal or higher rainfall experienced when there is positive IOD over Indian subcontinent. The rainfall over Indian subcontinent the variations are due to combined effect of El Nino and IOD [2,3].

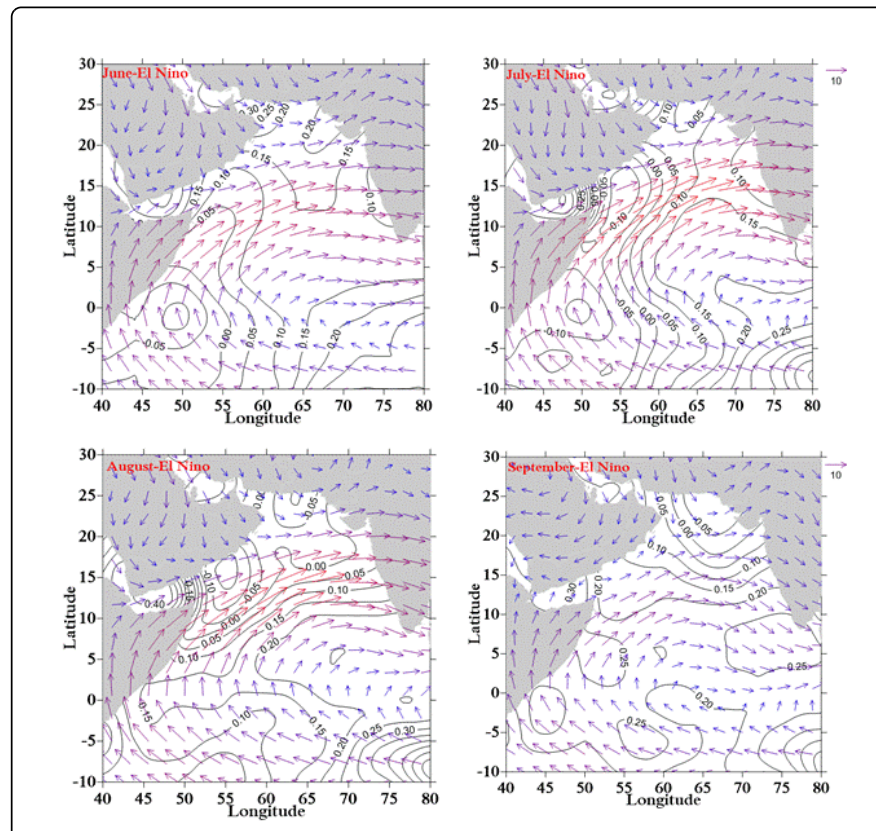

Figure 3: Variation of composites of SSTA and FLJ intensities during El Nino Years of JJAS during study period

The composite variations of FLJ and SSTA during La Nina years are given in the figure 4. FLJ intensity during June can be observed higher than that of El Nino. The SSTA are higher all over Arabian Sea. Southern and northern Arabian Sea experienced higher SSTA, However positive anomalies can be seen over central Arabian Sea with lower than either side. During July, an increase in FLJ intensity can be observed than June, however the SSTAs are lower. There is an adjustment in the areal extents of positive SSTA of 0.15 can be observed over equatorial region and extended $10^{\circ}$ either side. During August the FLJ intensities decreased than that of July with increment in SSTA. Higher SSTA can be observed from central to east side (west coast of India) of Arabian Sea. Northern Arabian Sea is experienced higher SSTA. In September FLJ further decreased and SSTA also decreased over central Arabian Sea. Over all Arabian Sea has experienced lower SSTA than August. If we compare the core area of FLJ, during June FLJ varied between $10 \mathrm{~m} / \mathrm{s}$ and $14 \mathrm{~m} / \mathrm{s}$ with SSTA between -0.6 and 0.6 . This variations show that there is an impact of 
FLJ on SSTA. The FLJ intensity has increased in the month of July between $14 \mathrm{~m} / \mathrm{s}$ and $16 \mathrm{~m} / \mathrm{s}$ with SSTA between -0.5 and 0.6. August month has experienced decrease in FLJ intensity than July. FLJ varied between $11 \mathrm{~m} / \mathrm{s}$ and $14 \mathrm{~m} / \mathrm{s}$ with SSTA between -0.5 and 0.6 similar to July. FLJ further decreased in the month of September than August and it is varied between $6 \mathrm{~m} / \mathrm{s}$ and $11 \mathrm{~m} / \mathrm{s}$ and SSTA between 0.5 and 0.5. The seasonal variations during La Nina periods also experienced higher FLJ intensity than El Nino. Except in 1984 all the other La Nina years are showing positive SSTA and FLJ intensity of $12 \mathrm{~m} / \mathrm{s}$ can be observed in all years of La Nina

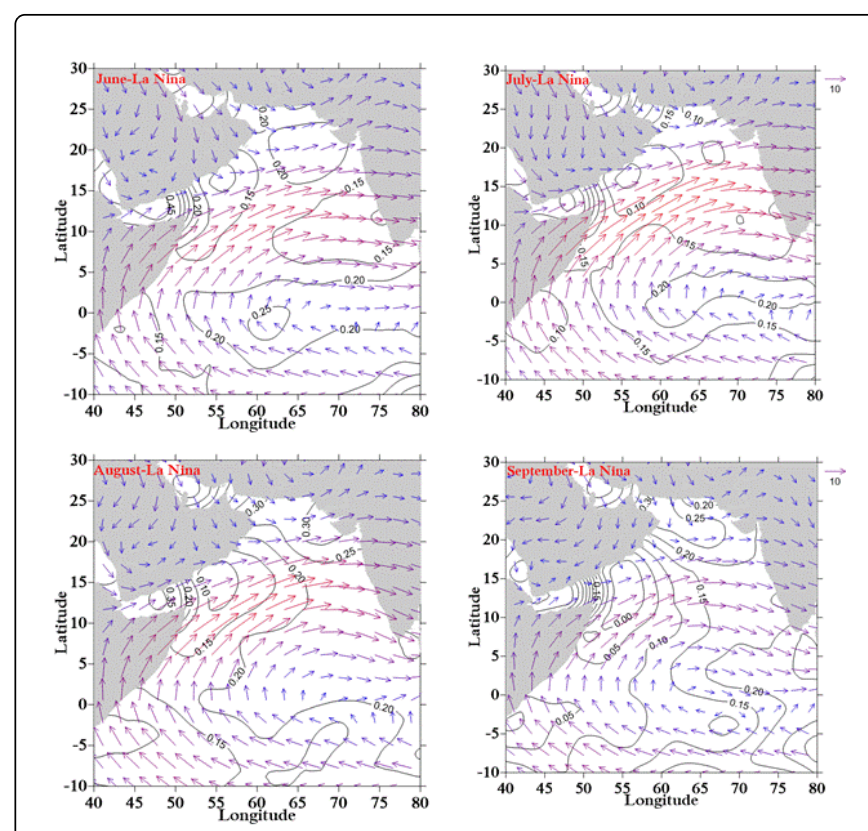

Figure 4: Variations of composites of SSTA and FLJ intensities during La Nina years for JJAS during study period

The years which are not El Nino and La Nina are declared as Normal years; show the following variations in FLJ and SSTA. Maximum positive SSTA of 0.5 can be observed during 2003 with FLJ intensity of $12 \mathrm{~m} / \mathrm{s}$. The lowest SSTA of -0.4 can be observed in 1985 with FLJ intensity of $11 \mathrm{~m} / \mathrm{s}$. The years having positive SSTA are associated with lower FLJ intensities with some exceptions. In the Indian Ocean, SST variability reflects the influence of ENSO and both forces and feeds back on the monsoons of India [21]. Statistical analyses of historical SST records indicate that the anomalous surface conditions of the Indian Ocean are highly correlated with ENSO events.

\section{Conclusions}

SSTAs are inversely proportional with FLJ intensities as is evident from the graphs during JJAS months. There are wide variations in the month of June and mean monthly averages of SSTA has also shown the variation of one degree with monsoon activity. So whenever SSTA decreases the FLJ intensities increase. Same is evident in the months of July, August and September. For the El Nino years the cloud cover is less and the SST is more and there is slight decrease in FLJ intensities. For the La Nina years the SSTA is less and FLJ intensities are relatively high. The SSTAs along with FLJ throw further light on the monsoon activity in month wise. In 2002 a typical El Nino year of moderate intensity but in phase with IOD results in very much deficit rainfall. This means the monsoon is not active in all the 3 months except August. Another El Nino year 1997 shows the following values of SSTAs for JJAS reveals the monsoon activity gradually improved up to August as evident from the decrease in SSTA and increase in FLJ. Similarly La Nina years 1998 and 2007, the SSTAs are decreasing from June through August and increased in September. There is no reduction in temperature as expected in the La Nina years. It is rather uniform with slight variations which are due to constant clouding in all the months resulting in uniform reduction and as a consequence, the SST is reduced uniformly and there is no much variation.

\section{Acknowledgements}

Authors are thankful for NCEP and NOAA for providing the wind and SST data.

\section{References}

1. Findlater J (1969) A major low level air current near the Indian Ocean during the northern summer. Q J Roy Meteor Soc 95: 362-380.

2. Pushpanjali B, Subrahmanyam MV, Murty KPRV (2013) Findlater Jet Intensity and Characteristics in Relation to Indian Summer Monsoon. 1: 47-64.

3. Leal MD, Levins MB (2013) Monsoons: Formation, Environmental Monitoring and Impact Assessment. Nova publications, USA.

4. Saha KR (1970a) Zonal anomaly of sea surface temperature in equatorial Indian Ocean and its possible effect upon monsoon circulation. Tellus 22: 403-409.

5. Saha KR (1970b) Air and water vapor transport across the equator in western Indian Ocean during northern summer. Tellus 22: 681-687.

6. Saha KR (1974) Some aspects of the Arabian Sea summer monsoon. Tellus 26: 464476 .

7. Lindzen RS, Nigam S (1987) On the role of Sea Surface Temperature Gradients in forcing the Low Level Winds and Convergence in the Tropics. J Atmos Sci 44: 2418-2436.

8. Shukla J (1975) Effect of Arabian Sea-surface temperature anomaly on Indian summer monsoon: A numerical experiment with GFDL model. J Atmos Sci 32: 503-511.

9. Kershaw R (1988) The Effect of a sea surface temperature anomaly on a prediction of the onset of the southwest monsoon over India. Q J Roy Meteor Soc 114: 325-345.

10. Yang S, Lau KM (1998) Influences of sea surface temperature.

11. Rao KG, Goswami BN (1988) Interannual variations of the SST over the Arabian Sea and the Indian monsoon: A new perspective. Mon Wea Rev $116558-568$.

12. Shukla J, Fennessy M (1994) Simulation and predictability of monsoons. 567-575.

13. Wolter K, Hastenrath S (1989) Annual cycle and long term trends of circulation and climate variability over the Tropical Oceans. J Climate 2: 1329-1351.

14. Klein SA, Soden BJ, Lau NC (1999) Remote Sea surface temperature variations during ENSO: Evidence for a tropical atmospheric bridge. J Climate 12: 917-932.

15. Krishnamurthy V, Kirtman BP (2003) Variability of the Indian Ocean: Relation to monsoon and ENSO. Q J Roy Meteor Soc 129: 1623-1646.

16. Shukla J (1987) Interannual variability of monsoons. In Fein JS, Stephens PL Monsoons. Wiley and Sons 399-463.

17. Weare BC (1979) A statistical study of the relationship between ocean surface temperatures and Indian monsoon. J Atmos Sci 36: 2279-2291.

18. Reynolds RW, Smith TM, Liu C, Chelton DB, Casey KS, et al. (2007) Daily high-resolution blended analyses for sea surface temperature. J Climate 20: 5473-5496. 
Citation: Pushpanjali B, Subrahmanyam MV, Vittal Murty KPR (2014) Sea Surface Temperature and Find Later Jet Variations over Arabian Sea During Summer Monsoon. J Climatol Weather Forecasting 2: 111. doi:10.4172/2332-2594.1000111

19. Kalnay E, Kanamitsu M, Kistler R, Collins W, Deaven D, et al. (1996) The NCEP/NCAR 40-Year Reanalysis Project. Bull Amer Meteor Soc, 77: 437-471.

20. Luis AJ, Kawamura H (2004) Air-Sea Interaction, Coastal Circulation and Primary Production in the Eastern Arabian Sea: A Review. J Oceanogr 60: 205-218.

21. Hastenrath S (1988) Climate and Circulation of the Tropics. 